ful means of stimulating high technology in the United States; the snag was that many governments had good reasons for not opting out of SDI. But, equally, there was no way of making sure that the plan called Eureka was not another way of advancing French claims to European leadership in technology, or perhaps even a way of persuading other governments to contribute to French advancement. For why else, the sceptics were asking earlier in the year, has France been urging technical collaboration on the rest of Europe at least since 1968, when M. Pierre Aigrain (then in the French government, now a director of the French Thomson company) tried on his government's behalf to persuade the European Communities to joint action? During M. François Mitterrand's presidency, the exhortations to technical collaboration have been even more frequent and insistent.

The surprise is that other governments in Western Europe seem at last to have taken to listening to what the French are saying. After two decades of scepticism, the belief that France may have been right all along has begun to gain ground. So much, at least, appears to have been the impression they created at the ministerial meeting on Eureka held at Hannover earlier this month. What seems to have happened in this economically disappointing year is that Western Europe has become collectively despondent about its technical future. Most governments are trying hard to succeed in high technology; most of them are presented every other day with evidence of how difficult it is to succeed in the face of competition from Japan and the United States. It is not surprising that one participant at Hannover said that European governments are now "running scared".

So, almost by chance, Mitterrand's Eureka will succeed when his and his predecessors' efforts in the same direction have mostly failed. The French president deserves credit for his persistence, the other governments of Western Europe for their new-found realism. But it is one thing to be agreed on a common cause and quite another to be sure of attaining it. The practical question still to be answered is whether mechanisms can be found that will enable Eureka to deliver the prizes its supporters promise. Two features of Eureka have so far been agreed. The framework of collaboration will be wider than the European Communities as such, so as to include Austria, Sweden and Switzerland in particular. And the programme will be supported not by another huge pot of public money, but by the funds of those most likely to benefit, the companies that decide to engage in transnational projects with each other.

On the face of things, it is not obvious why European companies should not collaborate with each other on worthwhile technical projects without France's banner labelled Eureka. Although the European Communities have regulations to prevent anti-competitive collusion by competing companies, these are neither as explicit as in the United States, nor are the penalties of transgression as fearsome. Part of the explanation for the poverty of international collaboration in Europe in past decades must surely be the conservatism of even progressive European industrial companies, many of whom still consider themselves as bitter rivals for the same block of overseas trade, that with the United States in particular. There is a chance that exhortation by itself may change this state of affairs, in which case Eureka may be very cheap. More probably, there are technical projects yet to be devised where public money will help to oil rusty wheels.

European governments should also recognize that the kind of collaboration foreseen by Eureka cannot be the basis of longterm economic success. It may help, in the short run, if more companies collaborate on the development of improved products, but either the agreements will then lapse and the companies will revert to rivalry, or they will find they have a successful product which they can market successfully only through some commonly owned channel, perhaps even an independent company in its own right. They will also discover, on the way to success of that kind, that the most wholehearted collaboration cannot succeed if the products whose development is intended are not sold competitively. The lesson from Japan on this point is clear; Japanese companies have succeeded in the export of high-quality technological products only because their domestic market is even more demanding than those abroad. So will European governments follow the logic of the enterprise on which they have engaged in Eureka, and agree that success entails the banishment of restrictive practices on public purchasing; of the regulations and unwritten rules by which governments in Europe try to preserve the national identity of their domiciled companies; and of the barriers that persist to the free movement of academics and their students from one part of Europe to another? Unless governments agree that these impediments to efficiency are long-term barriers to success in high technology, Eureka will fail.

\section{Honest pennies to earn}

\section{Britain's environment research council should} count again the costs of success.

THE British Natural Environment Research Council may fear that there is no way in which it can win friends, or placate its critics, but there is an awkward contradiction built into the way it is compelled to operate on a shrinking public budget. The framework of the inconsistency dates to the Rothschild reorganization of British civil science in 1971, but the issue has been sharpened only in the past five years. Rothschild, it will be remembered, argued that part of publicly supported research should be regarded as applied research, which should by rights be paid for by the ultimate beneficiaries (called customers), whose proxies would be government departments. So, when the British government accepted the formula, nearly a half of the council's budget (which proportion has since shrunk), was transferred to departments such as agriculture (interested in environmental consequences of fertilizer usage), the environment (interested in the environment) and energy (interested in natural resources). With the passage of time, departmental interests have been attenuated, and their willingness to pay for research has correspondingly declined. So the research council, to keep its establishments occupied, has been forced into the market, selling itself as a research contractor.

Earlier this week (see p.307), the council was rightly boasting of its success in selling its technique of side-scanning sonar to the US Geological Survey, which has commissioned it to carry out a survey of the continental shelf off the United States. Now the technique has been licensed to a British company which will, no doubt, be able to establish a profitable business elsewhere overseas, from which the council will also (rightly) profit. But there are other fields in which the council's success as a contractor for research has not been as welcome. Thus the British Geological Survey, originally established so as to provide the United Kingdom with a knowledge of the rocks and resources on which it rests, has been forced by penury to set up as a contractor for a wide variety of geological survey work, much of it well within the field of competence of private geological survey companies. This is one of the minor bones of contention that will no doubt be dealt with by the committee of inquiry now under way.

The perplexing question is how it can be right, even admirable. that the council should sell its sonar technology commercially while being criticized for competing with private organizations in geological survey work. The superficial answer is that there is a vast difference between a technique (such as side-scan sonar) where there are no immediate competitors and one (such as geological survey) where there are all too many. The more durable answer is that the role of publicly supported research enterprises working in the field of applications should be to stimulate companies working in the private sector, never to compete with them. It is probably a fault of the British economic system that there was no small company eager to build a future around the side-scanning sonar that is now a feather in the council's cap, in which case the council should have been worrying to stimulate a company of that kind. What is needed for the future is a mechanism for telling when public research must stop acting as an entrepreneur, becoming a midwife for others. 